\title{
FLEXURAL BEHAVIOR OF FRP BARS AFTER EXPOSURE TO ELEVATED TEMPERATURES
}

\author{
Sherif E. El Gamal ${ }^{1,2}$ *, Abdulrahman M. Al-Fahdi ${ }^{1}$, Mohammed Meddah ${ }^{1}$, Abdullah Al-Saidy ${ }^{1}$, and \\ Kazi Md Abu Sohel ${ }^{1}$ \\ ${ }^{1}$ Civil and Architectural Engineering, Sultan Qaboos University, Muscat, Oman \\ ${ }^{2}$ Menoufia University, Shebin El-Kom, Egypt
}

\begin{abstract}
This study investigates the flexural behavior of fibre-reinforced polymer (FRP) bars after being subjected to different levels of elevated temperatures $\left(100,200\right.$ and $\left.300^{\circ} \mathrm{C}\right)$. Three types of glass FRP bars (ribbed, sand coated, and helically wrapped) and one type of carbon FRP bars (sand coated) were used in this study. Two testing scenarios were used: (a) testing specimens immediately after heating and (b) keeping specimens to cool down to room temperature before testing. Test results showed that as the temperature increased the flexural strength and modulus of the tested FRP bars decreased. At temperatures higher than the glass transition temperature $\left(\mathrm{T}_{\mathrm{g}}\right)$, significant flexural strength and modulus losses were recorded. Smaller diameter bars showed better residual flexural strength and modulus than the larger diameter bars. The immediately tested bars showed significant strength and modulus losses compared to bars tested after cooling. Different types of GFRP bars showed comparable results. However, the helically wrapped bars showed the highest flexural strength losses (37 and 60\%) while the sand coated bars showed the lowest losses (29 and 39\%) after exposure to 200 and $300^{\circ} \mathrm{C}$, respectively. The carbon FRP bars showed residual flexural strengths comparable to those recorded for the GFRP bars; however, they showed lower residual flexural modulus after being subjected to 200 and $300^{\circ} \mathrm{C}$.
\end{abstract}

Keywords: Fibre-reinforced polymer bars; FRP; Glass FRP; Carbon FRP; Flexural strength; Flexural modulus; Elevated temperatures; Bar diameters.

\section{سلوك الإنثاء لقضبان البوليمر المقوى بالألياف بعد تعرضها لارجات حرارة مرتفعة}$$
\text { شريف الجمل, عبدالرحمن الفهي, محمد مداح, عبدالله السعيدي, و كازي ابو سهيل }
$$ \\ الملفص: تبحث هذه الدر اسة في سلوك الانثناء لقضبان البوليمر المقوى بالألياف بعد تعرضها لمستويات مختلفة من درجات

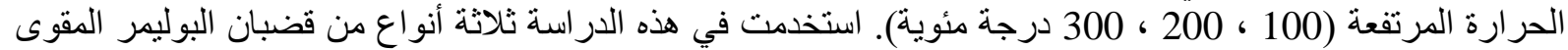

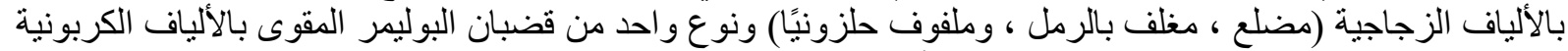

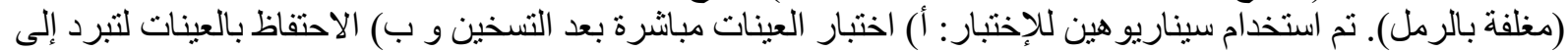

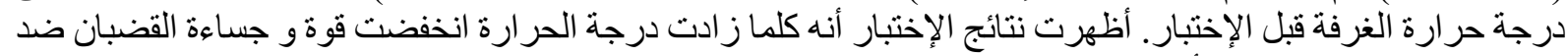

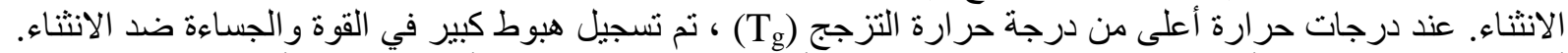

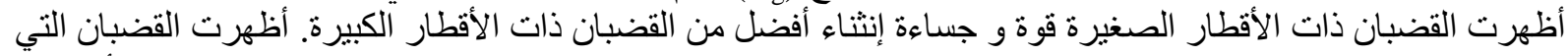

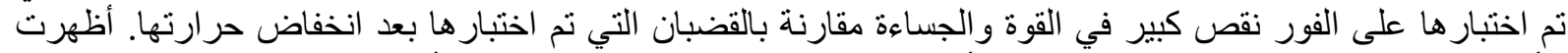

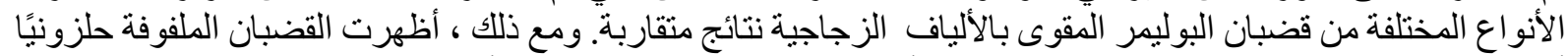

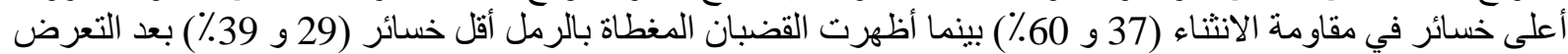

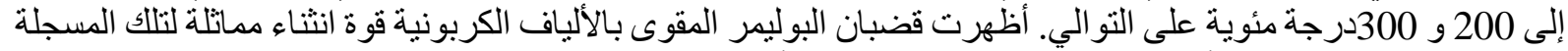 \\ لقضبان البوليمر المقوى بالألياف الزجاجية ؛ ومع ذللك ، فقد أظهرت معامل جساءة منخفض بعد تعرضها لـ لـ 200 و 300




\section{INTRODUCTION}

In recent years, Fiber Reinforced Polymers (FRP) have become one of the promising reinforcing materials in concrete structures. FRP reinforcing bars can be used instead of steel bars in reinforced concrete (RC) structures because of their excellent properties, which include corrosion resistance, high strength-to-weight ratio, appropriate fatigue performance, electric insulation and easy cutting and handling (El-Gamal et al. 2014). These advantages increased their use to repair existing structures (Al-Saidy et al. 2015, 2017; El-Gamal et al. 2019). They also increased their use instead of steel bars in several new reinforced concrete (RC) structures in corrosive environments such as bridge deck slabs, parking garage slabs, RC pavements, and RC columns (Benmokrane et al. 2007, 2008; El-Gamal et al. 2009; Thébeau et al. 2010; ElGamal et al. 2010; Bouguerra et al, 2011; Dulude et al. 2011; El-Gamal and Alshareedah 2020 a, b). On the other hand, they have some disadvantages compared to steel including no ductility, lower elastic modulus and shear strength. In addition, they are very sensitive to elevated temperatures (Ashrafi et al. 2017; Bazli and Abolfazli 2020; Jafarzadeh and Nematzadeh 2020)

The wide use of FRP bars in concrete structures led to new challenges for engineers. One of these challenges is the performance of FRP bars when subjected to elevated temperatures. FRP bars performance is poor under elevated temperatures. As the temperature increases, the matrix softens at the glass transition temperature level $\left(\mathrm{T}_{\mathrm{g}}\right)$. Above $\mathrm{T}_{\mathrm{g}}$, the matrix elastic modulus significantly reduces due to a change in its molecular structure. The thermal properties of fibres, however, are better than the matrix and can continue sustaining the load in a longitudinal direction until reaching the temperature level of the fibres. Engineers when designing a structure must consider the time that the structure can withstand high temperatures. Therefore, it is important to investigate the behavior of FRP bars subjected to elevated temperatures. Robert and Benmokrane (2010) investigated the tensile strength, shear strength and flexural strength of one type of glass FRP (GFRP) bar subjected to elevated temperatures. The elevated temperature levels ranged between 100 and $325^{\circ} \mathrm{C}$. The results showed that the shear and the flexural strengths were much more sensitive to high temperature than the tensile strength. The flexural strength of the GFRP bars increased when the temperature decreased. At $120^{\circ} \mathrm{C}$, the mechanical strength and flexural modulus dropped because of the change of the state of the polymer.

Alsayed et al. (2012) investigated the tensile properties of GFRP bars subjected to elevated temperatures for different periods. The study included two groups of specimens. The first group was 60 specimens without concrete cover (bare bars) with $1 \mathrm{~m}$ length. While the second group consisted of 60 specimens covered with concrete to represent the actual case when using the GFRP bars in concrete. The elevated temperatures used were 100,200 and $300^{\circ} \mathrm{C}$. The bars were tested in tension after exposure to the elevated temperatures. The authors concluded that the tensile strength decreased as the level of temperature or exposure period increased. The losses of tensile strength ranged between 3.1 to $35.1 \%$ and 9.7 to $41.9 \%$ for concrete-covered and bare GFRP bars, respectively.

Maranan et al. (2014) studied the flexural behavior of sand-coated GFRP bars of different diameters subjected to elevated temperatures up to $150^{\circ} \mathrm{C}$. As the temperature increased, the flexural strength and modulus of the GFRP bars decreased. When approaches the $T_{g}$ of the bars, the polymer changed from glassy (hard) material to rubbery (soft) material. The polymer begins to lose the ability to hold the fibre together and transfer stresses from one fibre to another. For all temperatures from 21 to $80^{\circ} \mathrm{C}$, the load increased linearly with deflection up to failure. In addition, temperatures from 100 to $150^{\circ} \mathrm{C}$ exhibited a non-linear behavior and modulus degradation before reaching the maximum load because the $\mathrm{T}_{\mathrm{g}}$ of the bar was about $117^{\circ} \mathrm{C}$. The research recommended additional studies to provide further information that can be used to establish a relationship that can predict the tensile response of the GFRP bars from the bending response at elevated temperatures.

Ashrafi et al. (2017) investigated the physical and thermal properties of FRP bars subjected to elevated temperatures. The test specimens used were four types of FRP bars; sand-coated GFRP, helically wrapped CFRP, and grooved CFRP bars with two different resins (epoxy and vinyl ester). The research concluded that, as the temperature increased the tensile strength of the FRP bars decreased. Also, the bigger the diameter the greater tensile strength. The results of CFRP bars showed linear deformation until reaching the ultimate load. The critical temperatures of the sandcoated GFRP bars when losing $50 \%$ of its tensile strength were $300,375,377$ and $450^{\circ} \mathrm{C}$ for $4,6,8$, and $10 \mathrm{~mm}$ respectively. The critical temperatures of the three types of CFRP bars tested were 330, 360 and $450^{\circ} \mathrm{C}$, respectively.

Hamad et al. (2017) studied the effect of elevated temperatures on the mechanical properties of FRP bars and the bond behavior between FRP bars and concrete. The test specimens used were four types; sand-coated CFRP, helically wrapped Basalt FRP (BFRP), helically wrapped GFRP, and Steel bars. The elevated temperatures used ranged between 125 to $450^{\circ} \mathrm{C}$. After exposure to elevated temperatures, the specimens were left to cool in the air after taken from the electrical furnace. The tensile strength reduction of FRP bars was almost linear up to a critical temperature of $325^{\circ} \mathrm{C}$. At a temperature of $450^{\circ} \mathrm{C}$, the GFRP and BFRP bars melted and totally lost their tensile strength capacity. Steel bars had a minor reduction in tensile strength compared with the FRP bars. Among the FRP bars, the 
CFRP showed the highest bond strength with concrete because of their better surface characteristics. However, steel bars attained the highest bond strength and modulus. The study recommended additional experimental work using other types of commercially available FRP bars.

The literature shows that few studies investigated the flexural behavior of the FRP bars subjected to elevated temperatures and recommended conducting more research on this topic. In addition, these studies are limited to specific types and diameters of the FRP bars. Therefore, to enrich the knowledge about this topic, it was decided to conduct this research study to investigate the flexural behavior of different types and diameters of FRP bars exposed to elevated temperatures. Test parameters include the four types of FRP bars (sand-coated GFRP, helically wrapped GFRP, grooved GFRP, and sand-coated CFRP), three diameters of the grooved GFRP bars (10, 16 and 20 $\mathrm{mm})$, three target temperature levels $(100,200$ and $300^{\circ} \mathrm{C}$ ), and three exposure periods (1, 2 and 3 hours). In addition, two testing scenarios were investigated: a) testing specimens immediately after heating; and b) keeping specimens to cool down to room temperature before testing.

\section{EXPERIMENTAL WORK}

\subsection{FRP Bars}

Three different types of GFRP bars and one type of CFRP bars were used in this study. The GFRP bars included; a) grooved (G1) with nominal diameters of 10, 16 and $20 \mathrm{~mm}$; b) sand-coated (G2) with a nominal diameter of $10 \mathrm{~mm}$, and c) helically wrapped (G3) with a nominal diameter of $10 \mathrm{~mm}$. While sand-coated CFRP (C1) bar with a nominal diameter of $10 \mathrm{~mm}$ was used. Table 1 presents the list of FRP types, manufacturers and their properties. Figure 1 shows photos of the bars used in this investigation.

\subsection{Test Specimens and Parameters}

FRP bars were prepared for flexure tests. The length of all specimens was $240 \mathrm{~mm}$. The total number of specimens tested in this study was 99 specimens. Three specimens of each diameter were tested at room temperature as control specimens. The remaining specimens were exposed to temperatures of 100, 200, and $300^{\circ} \mathrm{C}$ for one hour. An electric furnace was used to heat up the specimens. The temperature was increased at a rate of $3^{\circ} \mathrm{C}$ degrees per minute until reaching the required temperature then was kept constant at the required temperature level. All the G1 specimens were tested using two testing scenarios. Half of them were tested immediately after taken out from the furnace. The other half was kept in the lab for one hour to cool down before testing. All other types of FRP bars were tested immediately after taken out from the furnace.

\subsection{Flexural Test Procedure}

All specimens were tested under a three-point bending test set-up. The flexural tests were conducted in accordance with the ASTM D790 standard (ASTM D790-03, 2003). The clear span between supports was $180 \mathrm{~mm}$ and the overhangs were $30 \mathrm{~mm}$. The tests were carried out using a $600 \mathrm{kN}$ MTS machine under a loading rate of $4 \mathrm{~mm} / \mathrm{min}$. The applied load and the mid-span deflection were recorded using a data logger. Figure 2 shows a typical specimen during the testing.

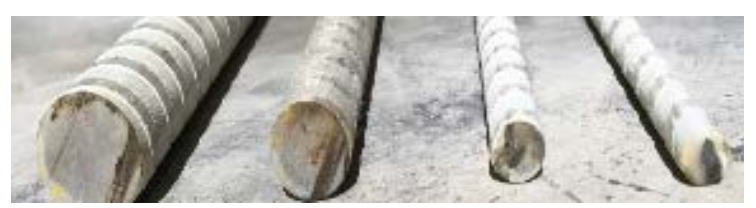

(a) Grooved GFRP Bars (G1).

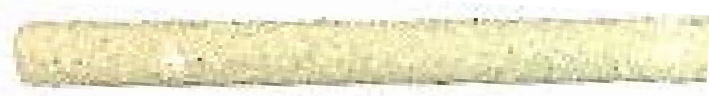

(b) Sand-Coated GFRP Bar (G2).

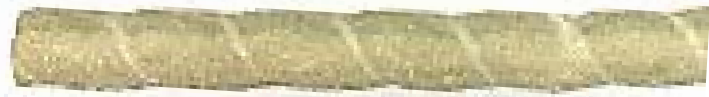

(c) Helically wrapped GFRP Bar (G3).

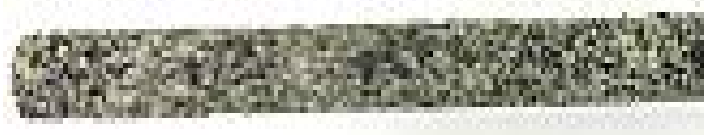

(d) Sand-Coated CFRP Bar (C1).

Figure 1. FRP bars used in this study.

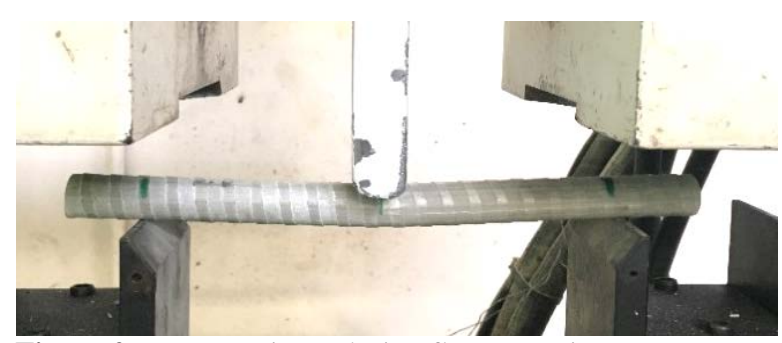

Figure 2. FRP specimen during flexure testing.

Table 1. Properties of FRP bars used in this study.

\begin{tabular}{|c|c|c|c|c|c|c|}
\hline \multirow[t]{2}{*}{ Type } & \multicolumn{5}{|c|}{ Glass } & \multirow{2}{*}{$\begin{array}{c}\text { Carbor } \\
\mathrm{C1}^{\mathrm{b}}\end{array}$} \\
\hline & & $\mathrm{G} 1^{\mathrm{a}}$ & & $\mathrm{G} 2^{\mathrm{b}}$ & $\mathrm{G}^{\mathrm{c}}$ & \\
\hline Nominal & 10 & 16 & 20 & 10 & 10 & 10 \\
\hline Diameter & & & & & & \\
\hline Tensile & 1150 & 1102 & 1094 & 1185 & 849 & 1596 \\
\hline $\begin{array}{c}\text { Strength } \\
\text { (MPa) }\end{array}$ & & & & & & \\
\hline Tensile & 60.5 & 61.2 & 66.4 & 52.3 & 48.8 & 120 \\
\hline $\begin{array}{c}\text { Modulus } \\
\text { (GPa) }\end{array}$ & & & & & & \\
\hline $\begin{array}{l}\text { Ultimate } \\
\text { strain } \\
\text { (\%) }\end{array}$ & 1.9 & 1.8 & 1.65 & 2.26 & 1.81 & 1.33 \\
\hline $\begin{array}{c}\text { Area } \\
\left(\mathrm{mm}^{2}\right)\end{array}$ & 66.5 & 199 & 284 & 71.3 & 71.3 & 71.3 \\
\hline
\end{tabular}

a Made in UAE; ${ }^{\text {a }}$ made in Canada; ${ }^{\mathrm{c}}$ made in the USA. 


\section{TEST RESULTS AND DISCUSSIONS 3.1. Summary of Results}

Table 2 summarizes the experimental test results of all tested bars. The values of the flexural strength and modulus presented are the average values from three specimens. The flexural strength $\left(f_{b}\right)$ and the flexural modulus $\left(E_{b}\right)$ were calculated using Eqn. (1) and Eqn. (2), respectively. More details about these equations can be found in Appendix A and Appendix B, respectively.

$f_{b}=\frac{8 F L}{\pi d_{b}^{3}}$

$E_{b}=\frac{\left(F_{50}-F_{20}\right)}{\left(\Delta_{50}-\Delta_{20}\right)} \frac{4 L^{3}}{3 \pi d_{b}^{4}}$

where $F, L$, and $d_{b}$, are the maximum concentrated load, clear span, and nominal diameter of the bars, respectively; $F_{50}$ and $F_{20}$ are the concentrated load at 50 and $20 \%$ of the maximum load, respectively. $\Delta_{50}$ and $\Delta_{20}$ are the mid-span deflection at $F_{50}$ and $F_{20}$, respectively.

The values of $F$ and $\Delta$ in Eqn. (2) were obtained from the load-deflection curve of each bar. Specimens exposed to 100 and $200^{\circ} \mathrm{C}$ showed a linear relationship between the load and mid-span deflection until failure for all FRP types. Some of the specimens exposed to $300^{\circ} \mathrm{C}$ show nonlinear behavior at higher loads levels close to failure.

\subsection{Failure Modes of Tested Bars}

The general failure mode of most FRP bars after testing is defined by crushing of the bars in the compression zone and rupture of fibres in the tension side as shown in Fig. 3(a). Some of the $20 \mathrm{~mm}$ diameter bars showed an interlaminar shear failure at high temperatures (200 and $300^{\circ} \mathrm{C}$ ) as shown in Fig. 3(b). It occurs due to high horizontal shear force that affected the weak matrix at high temperatures.

\subsection{Effect of Temperature Level and Bar Diameter (Type G1 Bars)}

Figures 4(a) and 4(b) represent the residual flexural strength of type G1 bars as a function of temperature level and bar diameter for both immediate and cooling testing scenarios, respectively. Figure 4(a) shows that, in the immediate scenario, the residual flexural strength decreased as the temperature level increased. After exposure for one hour to $100^{\circ} \mathrm{C}$, the residual flexural strengths ranged between 78 to $84 \%$ of the control samples. The residual flexure strength was significantly affected after exposure to 200 and $300^{\circ} \mathrm{C}$. At $200^{\circ} \mathrm{C}$, the residual flexural strengths ranged between 19 and $67 \%$ and then reduced at $300^{\circ} \mathrm{C}$ to range between 11 and $48 \%$. This decrease in the residual flexural strength at higher temperature levels could be related to the matrix softening. As the temperature exceeds the $T_{g}$ temperature, the matrix elastic modulus significantly reduces due to a change in its molecular structure and results in lower efficiency in transferring shear forces between fibres, consequently, results in lower flexural strength of the FRP bars. Fig. 4(a) also shows that, in the immediate scenario, the flexural strength losses at $100^{\circ} \mathrm{C}$ was not affected by the bar diameter where the matrix at this temperature level was not significantly affected and the failure was dominant by the fibres. At this temperature level, the residual flexure strengths were 78,84 , and $84 \%$ for the 10,16 , and $20 \mathrm{~mm}$ diameter bars, respectively. At 200 and $300^{\circ} \mathrm{C}$ (higher than the Tg), it can be noticed that the residual strength decreased as the bar diameter increased. At $200^{\circ} \mathrm{C}$, the residual flexural strengths were 67,32 , and $19 \%$ for the 10,16 , and $20 \mathrm{~mm}$ diameter bars, respectively. Similar observations were recorded at $300^{\circ} \mathrm{C}$ where the residual flexural strengths were 48, 31 and 11\%, respectively. At these temperature levels, matrices become weak and the shear strength of the matrix dominants the failure. In smaller diameter bars, there are lower horizontal shear stresses in the matrix, which delays the matrix failure and results in higher residual strength. These shear stresses increase as the bar diameters increase and result in earlier failure of the matrix and lower flexural strength. This can be seen from the interlaminar shear failure observed in the 20 $\mathrm{mm}$ bars at high temperatures as shown in Fig. 3(b). This agrees with previous research studies (Robert and Benmokrane 2010; Maranan et al. 2014).

In the cooling scenario (Fig. 4(b)), it can be noticed that the residual flexural strength was not significantly affected by increasing the temperature level or bar diameter. The flexural strength losses ranged between 5 and $8 \%, 4$ and 14\%, and 3 and 12\% for bars exposed to 100,200 and $300^{\circ} \mathrm{C}$ temperatures, respectively. This indicates that allowing the temperature of the specimens to cool down before testing enhanced their strength and resulted in residual flexural strengths close to those of the reference specimens. This shows that the matrix gained strength after cooling and were able to transfer the shear forces between the fibres, which resulted in the high flexural strength values compared to the immediate scenario.

Figures 5(a) and 5(b) show the residual flexural modulus of all G1 bars for both immediate and cooling specimens, respectively. The modulus results were consistent with the strongest results. It can be noticed that, for the immediate scenario, the modulus decreased as the temperature level increased. The residual flexural modulus was only about $18 \%$ at 200 and $300^{\circ} \mathrm{C}$ for the 16 and $20 \mathrm{~mm}$ bars (losses of about $82 \%)$. This again could be related to the weakness of the resin due to high temperatures especially for bigger bars that did not lose heat during immediate testing. For cooling specimens, the used temperature levels have a slight effect on the flexural modulus of the tested bars. For example, the residual flexural moduli of the 10, 16 and $20 \mathrm{~mm}$ was 99,98 and $92 \%$ at $200^{\circ} \mathrm{C}$ and 100,98 and $84 \%$ at $300^{\circ} \mathrm{C}$, respectively. 
Table 2. Flexural strength and modulus for test specimens.

\begin{tabular}{|c|c|c|c|c|c|c|c|c|c|c|c|c|}
\hline \multirow{3}{*}{$\begin{array}{c}\text { Types } \\
\text { Diameter } \\
\text { Specimen }\end{array}$} & \multicolumn{6}{|c|}{ G1 } & \multirow{2}{*}{\multicolumn{2}{|c|}{$\begin{array}{c}\mathrm{G} 2 \\
10 \mathrm{~mm}\end{array}$}} & \multirow{2}{*}{\multicolumn{2}{|c|}{$\begin{array}{c}\mathrm{G} 3 \\
10 \mathrm{~mm}\end{array}$}} & \multirow{2}{*}{\multicolumn{2}{|c|}{$\begin{array}{c}\mathrm{C} 1 \\
10 \mathrm{~mm}\end{array}$}} \\
\hline & & $\mathrm{mm}$ & & $\mathrm{mm}$ & & $\mathrm{mm}$ & & & & & & \\
\hline & $\begin{array}{c}f_{b} \\
(\mathrm{MPa})\end{array}$ & $E_{b}(\mathrm{GPa})$ & $\begin{array}{c}f_{b} \\
(\mathrm{MPa})\end{array}$ & $E_{b}(\mathrm{GPa})$ & $\begin{array}{c}f_{b} \\
(\mathrm{MPa})\end{array}$ & $E_{b}(\mathrm{GPa})$ & $\begin{array}{c}f_{b} \\
(\mathrm{MPa})\end{array}$ & $E_{b}(\mathrm{GPa})$ & $\begin{array}{c}f_{b} \\
(\mathrm{MPa})\end{array}$ & $E_{b}(\mathrm{GPa})$ & $\begin{array}{c}f_{b} \\
(\mathrm{MPa})\end{array}$ & $\begin{array}{c}E_{b} \\
(\mathrm{GPa})\end{array}$ \\
\hline $\begin{array}{c}\text { Room } \\
\text { Temperature }\end{array}$ & 1055 & 46.1 & 773 & 45.9 & 942 & 54.9 & 1131 & 37.7 & 814 & 34.1 & 830 & 80.0 \\
\hline $100-1 \mathrm{~h}-\mathrm{i}$ & 823 & 45.4 & 652 & 44.2 & 793 & 45.4 & 1080 & 37.3 & 732 & 33.6 & 700 & 79.8 \\
\hline 200-1h-i & 710 & 32.9 & 246 & 8.4 & 176 & 10.1 & 806 & 26.1 & 516 & 26.2 & 538 & 37.9 \\
\hline $300-1 h-i$ & 512 & 29.6 & 242 & 8.6 & 108 & 10.0 & 689 & 26.0 & 326 & 20.2 & 441 & 26.6 \\
\hline $100-1 h-C$ & 1005 & 45.0 & 735 & 46.0 & 865 & 51.8 & - & - & - & - & - & - \\
\hline 200-1h-C & 909 & 45.8 & 738 & 45.2 & 849 & 50.5 & - & - & - & - & - & - \\
\hline $300-1 \mathrm{~h}-\mathrm{C}$ & 933 & 46.0 & 724 & 44.8 & 918 & 45.9 & - & - & - & - & - & - \\
\hline
\end{tabular}

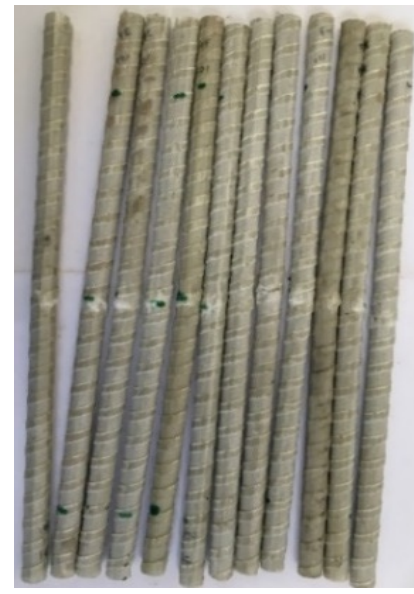

G1

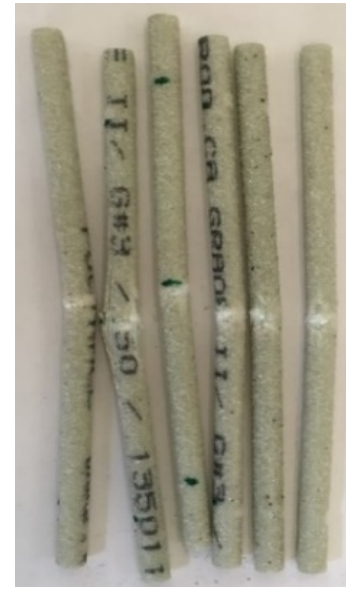

G2

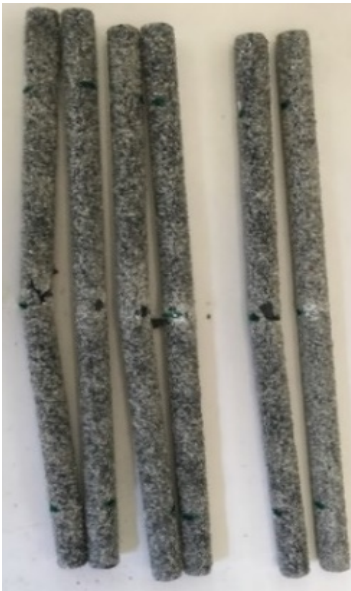

G1

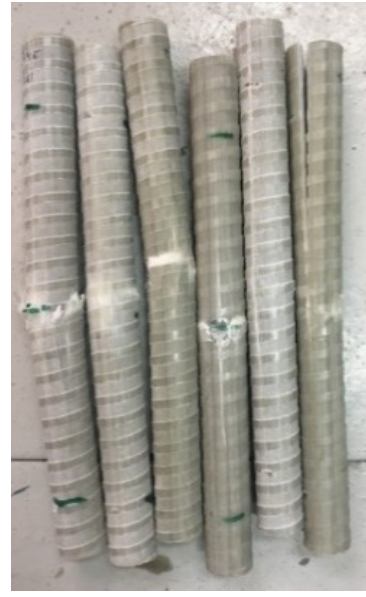

G1

(b) $20 \mathrm{~mm}$ diameter

(a) $10 \mathrm{~mm}$ diameter

Figure 3. The general typical failure mode of FRP bars after testing.

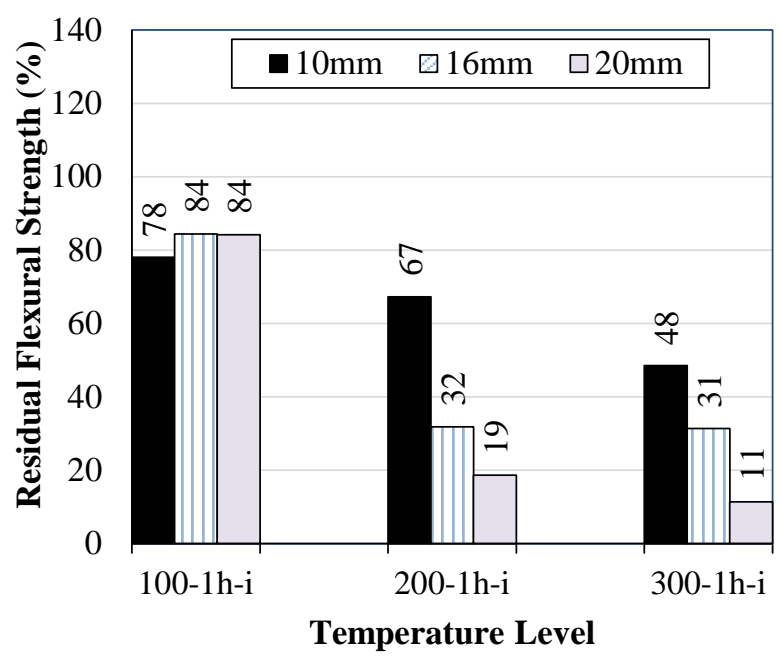

(a)

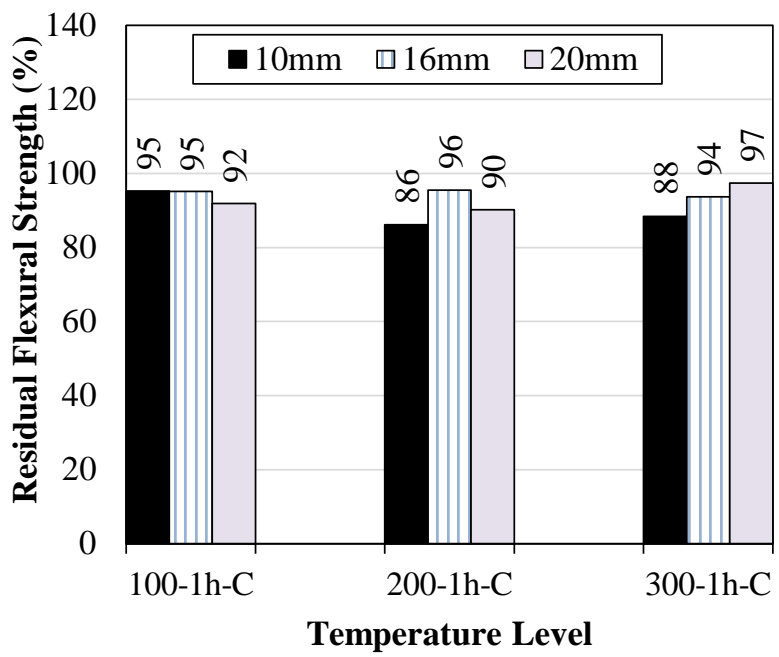

(b)

Figure 4. Residual flexural strength of G1 at different temperatures: (a) immediate; (b) after cooling. 


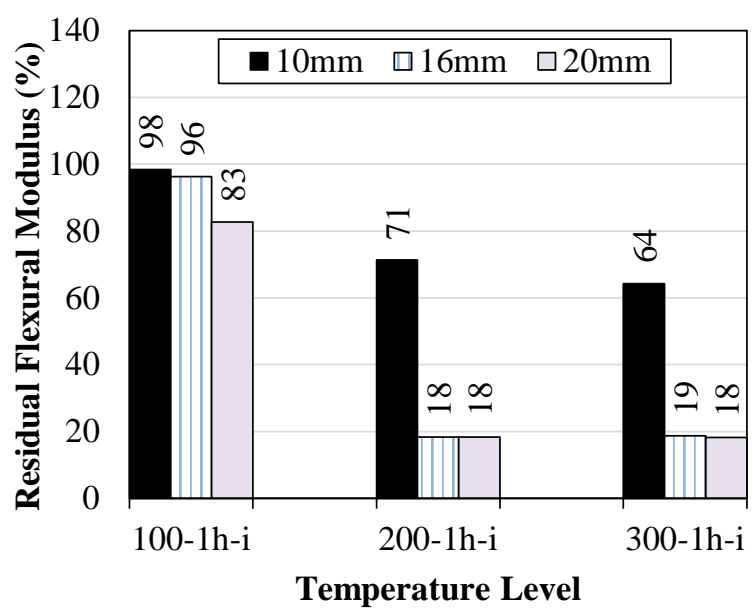

(a)

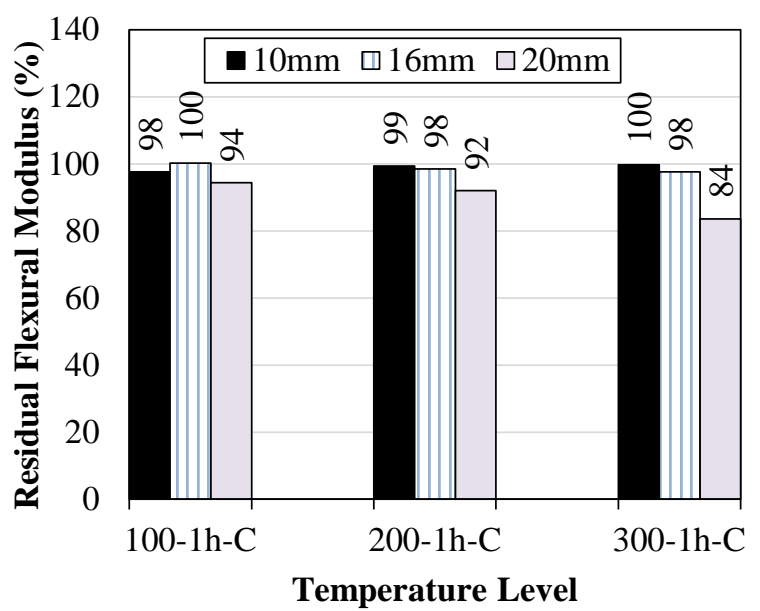

(b)

Figure 5. Residual flexural modulus of G1 at different temperatures: (a) immediate; and (b) after cooling.

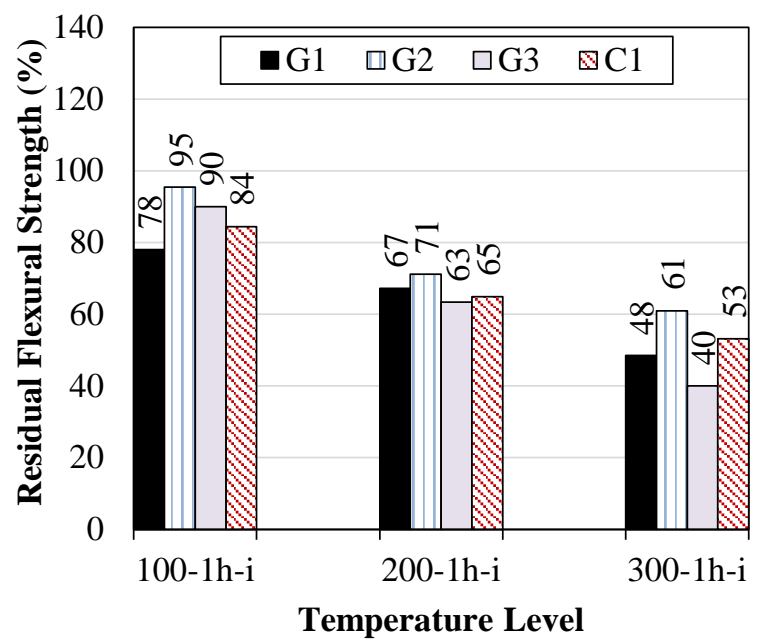

(a)

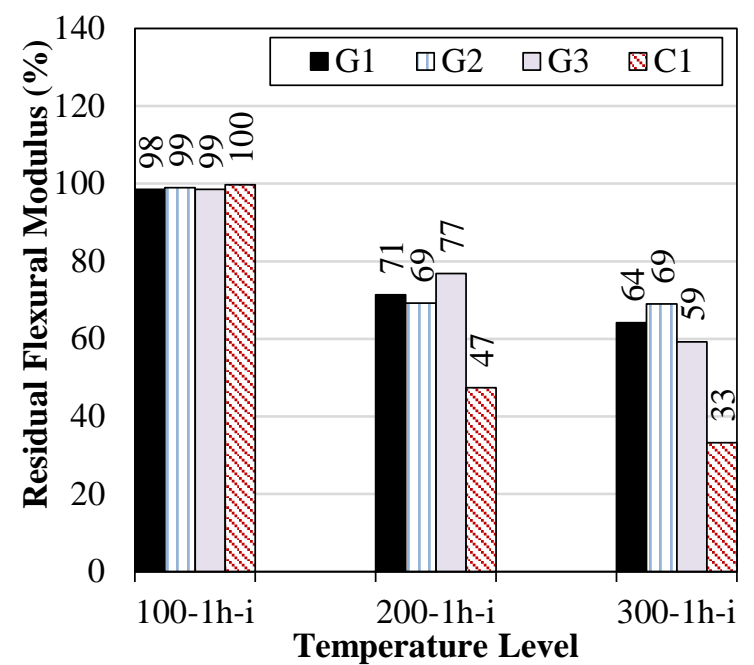

(b)

Figure 6. The behavior of different types of FRP bars exposed to different temperature levels: (a) residual flexural strength; (b) residual flexural modulus.

\subsection{Effect of FRP Type}

Figure (6a) shows the residual flexural strength of all types of FRP bars with a $10 \mathrm{~mm}$ diameter. Similar to type G1, the flexural strength of all FRP types decreased as the temperature level increased due to the resin decomposition at higher temperatures above the $T_{g}$ (around $120^{\circ} \mathrm{C}$ ). Therefore, a significant decrease of the flexural strength occurred because the polymer lost part of its ability to hold the fibre and to transfer the stresses between fibres. All types showed close residual flexure strengths at different temperatures. The residual flexure strength values ranged from 78 to $95 \%, 63$ to 71 , and 40 to $61 \%$ at 100,200 , and $300^{\circ} \mathrm{C}$, respectively. However, at all temperature levels, type G2 (sand coated GFRP bars) showed the highest residual flexural strength compared to other types. The relationship between the flexural modulus and temperature is shown in Fig. 6(b). It can be seen that the flexural modulus was not affected at $100^{\circ} \mathrm{C}$. For both 200 and $300^{\circ} \mathrm{C}$, the flexural modulus was significantly decreased for all FRP types. The residual flexural modulus of the GFRP bars at 200 and $300^{\circ} \mathrm{C}$ ranged from 69 to $77 \%$ and 59 to 69, respectively. The CFRP bars (C1), however, showed the lowest residual flexural modulus among all types with losses of about 53 and $67 \%$ at 200 and $300^{\circ} \mathrm{C}$, respectively. This may point to a weaker contact between the matrix and the carbon fibres at a temperature higher than the $T_{g}$. It may be also due to the type of matrix used in manufacturing the carbon bars. Additional studies are required in the future to clarify this point.

\section{CONCLUSION}

Based on the test results of this research, the following conclusions can be drawn: 
- The flexural strengths and moduli of all immediately tested specimens decreased as the temperature level increased. For all $10 \mathrm{~mm}$ diameter bars, the residual flexural strengths ranged between 40 and $61 \%$, while the residual flexure moduli ranged between 33 and 69\%, after exposure to $300^{\circ} \mathrm{C}$.

- Bars with larger diameters showed lower residual flexural strengths and moduli compared to smaller diameter bars. The bars with 10, 16, and $20 \mathrm{~mm}$ diameters tested immediately after exposure to $300^{\circ} \mathrm{C}$ showed residual flexural strengths of 48,31 , and $11 \%$, respectively.

- At 200 and $300^{\circ} \mathrm{C}$, the immediately tested G1 specimens showed significant flexural strength and moduli losses (29 to 89\%) compared to the losses in the G1 bars tested after cooling to room temperature (0 to $16 \%$ ).

- All tested GFRP bars showed comparable behavior at different temperatures. However, type G3 showed the highest flexural strength losses (37 and $60 \%)$ and type G2 bars showed the lowest losses (29 and 39\%) after exposure to 200 and $300^{\circ} \mathrm{C}$, respectively.

- The carbon FRP bars showed residual flexural strength ratios comparable to those of the GFRP bars; however, they showed lower residual flexural modulus ratios at 200 and $300^{\circ} \mathrm{C}$.

\section{CONFLICT OF INTEREST}

The authors declare no conflict of interest.

\section{FUNDING}

This study was funded by the Department of Civil and Architectural Engineering, College of Engineering, Sultan Qaboos University, Oman.

\section{ACKNOWLEDGMENT}

The authors would like to acknowledge Sultan Qaboos University, the Civil and Architectural Engineering Department, and all the technicians at the structural laboratory for their help and support.

\section{REFERENCES}

Alsayed, S., Al-Salloum, Y., Almusallam, T., ElGamal, S., Aqel, M. (2012). Performance of Glass Fiber Reinforced Polymer Bars under Elevated Temperatures. Composites Part B, Vol. 43, pp. 2265-2271.

Ashrafi, H., Bazli, M., Najafabadi, M., Oskouei, A. (2017). The Effect of Mechanical and Thermal Properties of FRP Bars on Their Tensile Performance under Elevated Temperatures. Construction and Building Materials, Vol. 157, pp. 1001-1010.
ASTM D790-03 (2003). Standard Test Methods for Flexural Properties of Unreinforced and Reinforced Plastics and Electrical Insulating Materials. ASTM International, West Conshohocken, PA, USA.

Bazli M, Abolfazli M (2020), Mechanical Properties of Fibre Reinforced Polymers under Elevated Temperatures: An Overview. Polymers 12, 2600; doi:10.3390/polym12112600.

Benmokrane, B., Eisa, M., El-Gamel, S., Denis, T., ElSalakawy, E. (2008). Pavement system suiting local conditions. ACI Concrete International Magazine. November 2008: pp.34-39.

Benmokrane, B., El-Salakawy, E., El-Ragaby, A., and El-Gamal, S.E. (2007). Performance evaluation of innovative concrete bridge deck slabs reinforced with fibre-reinforced-polymer bars. Canadian Journal of Civil Engineering, 34(3), 298-310.

Bouguerra, K., Ahmed E.A., El-Gamal, S.E., and Benmokrane, B. (2011). Testing of full-scale concrete bridge deck slabs reinforced with Fiber Reinforced Polymer (FRP) bars. Construction and Building Materials Journal, Vol. 25, 3956-3965.

Dulude, C., Ahmed, E., El-Gamal, S., Benmokrane, B. (2011). Testing of large-scale two-way concrete slabs reinforced with GFRP bars. Advances in FRP Composites in Civil Engineering, 287-291.

El-Gamal, S.E., Abdul Rahman, B., Benmokrane, B (2010). Deflection Behavior of Concrete Beams Reinforced with Different Types of GFRP Bars. The 5th International Conference on FRP Composites in Civil Engineering, Beijing, China, Sept. 27-29

El-Gamal, S.E., Al-Nuaimi, A., Al-Saidy, A., AlLawati, A. (2014). Flexural strengthening of RC beams using near-surface mounted fibre reinforced polymers. The Brunei International Conference on Engineering and Technology, Institut Teknologi Brunei, Brunei Darussalam, November 1-3, 10p.

El-Gamal, S.E., AlShareedah, O. (2020a). The behavior of axially loaded low strength concrete columns reinforced with GFRP bars and spirals. Engineering Structures, 216, 110732

El-Gamal, S.E., AlShareedah, O. (2020b). Experimental study on the performance of circular concrete columns reinforced with GFRP under axial load. International Conference on Civil Infrastructure and Construction (CIC 2020), February 2-5, 2020, Doha, Qatar.

El-Gamal, S.E., Benmokrane, B., and El-Salakawy, E.F. (2009). Cracking and deflection behavior of one-way parking garage slabs reinforced with CFRP bars. ACI Special Publication, SP-264-3, 3352.

Hamad, R., Johari, M., Haddad, R. (2017). Mechanical properties and bond characteristics of different fiber reinforced polymer rebars at elevated temperatures. Construction and Building Materials, Vol. 142, pp. 521-535.

Hibbeler, R.C. (2018). Structural Analysis, $10^{\text {th }}$ Edition in SI Units, Pearson, Prentice Hall, pp. 700. 
Jafarzadeh H, Nematzadeh M (2020), Evaluation of post-heating flexural behavior of steel fiberreinforced high-strength concrete beams reinforced with FRP bars: Experimental and analytical results. Engineering Structures 225: 111292.

Maranan, G., Manalo, A., Karunasena, B., Benmokrane, B., Lutze, D. (2014). Flexural behavior of glass fibre reinforced polymer (GFRP) bars subjected to elevated temperature. The 23rd Australasian Conference on the Mechanics of Structures and Materials (ACMSM23), Vol. I,

Appendix A: Eqn. (1): Flexure Strength (fb) The flexural strength was derived using the following equations (Hibbler R.C. 2018):

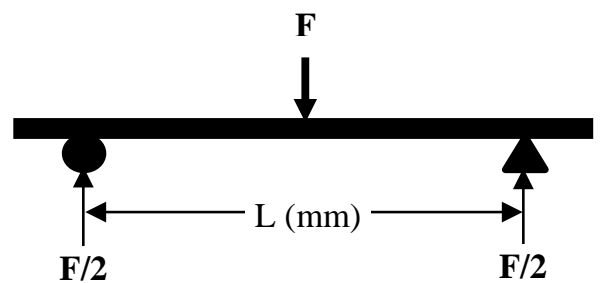

$f_{b}=\frac{M}{I} y$

(A1)

where $f_{b}$ is the flexural strength of the FRP bar

$(\mathrm{N} / \mathrm{mm} 2)$; $\mathrm{M}$ is maximum bending moment under the load (N.mm); I is the moment of inertia of the FRP bar about its neutral axis (mm4), y is the perpendicular distance from the neutral axis of the FRP bar to its outer surface (mm).

$M=\frac{F}{2}\left(\frac{L}{2}\right)=\frac{F L}{4}$

$y=\frac{d}{2}$

$I=0.25 \pi\left(\frac{d}{2}\right)^{4}$

where, $d$ is the diameter of the GFRP bar (mm) Substituting Eqns. (A2), (A3) and (A4) into Eqn. (A1) results in:

$f_{b}=\frac{F L}{4 \times 0.25 \pi\left(\frac{d}{2}\right)^{4}} \frac{d}{2}$

$f_{b}=\frac{8 F L}{\pi d^{3}}$
Byron Bay.

Robert, M., Benmokrane, B. (2010). Behavior of GFRP reinforcing bars subjected to extreme temperatures. Journal of Composites for Construction, Vol. 14, No. 1, pp. 353-360.

Thébeau, D., Benmokrane, B., and El-Gamal S.E. (2010). Three-year performance of continuously reinforced concrete pavement with GFRP bars. The 11th International Symposium on Concrete Roads, Seville, Spain, October 13-15, 11p.

Appendix B: Eqn. (2): Flexure Modulus, (Eb)

The calculations of the flexural modulus were derived using the double integration method given in (Hibbler R.C. 2018).

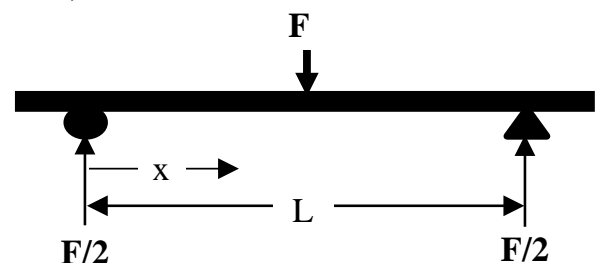

$\frac{d^{2} v}{d x^{2}}=\frac{M}{E I}=\frac{F x}{2 E I}$

$E I \frac{d v}{d x}=\int_{0}^{x} \frac{F x}{2} d x=\frac{F x^{2}}{4}+C 1$

$E I \Delta=\int_{0}^{x}\left(\frac{F x^{2}}{4}+C 1\right) d x=\frac{F x^{3}}{12}+C 1 x+C 2$

At $x=\frac{L}{2} \quad \rightarrow \quad \frac{d v}{d x}=0$

From $1, \quad 0=\frac{F\left(\frac{L}{2}\right)^{2}}{4}+C 1 \rightarrow C 1=-\frac{F L^{2}}{16}$

At $x=0 \quad \rightarrow \quad \Delta=0$

From 2, $0=0+0+C 2 \rightarrow C 2=0$

By substituting the values of C1 and C2 into Eqn. (B3),

$E I \Delta=\frac{F x^{3}}{12}-\frac{F L^{2}}{16} x$

At $\mathrm{x}=\mathrm{L} / 2, \Delta=\Delta_{\max }$

$E I \Delta_{\max }=\frac{F\left(\frac{L}{2}\right)^{3}}{12}-\frac{F L^{2}}{12}\left(\frac{L}{2}\right)=\frac{-2 F L^{3}}{96}$

$E_{b}=\frac{-2 F L^{3}}{96 I \Delta_{\max }}=\frac{-F}{\Delta_{\max }} \frac{2 L^{3}}{96\left(0.25 \pi\left(\frac{d}{2}\right)^{4}\right)}$

$E_{b}=\frac{-F}{\Delta} \frac{4 L^{3}}{3 \pi d^{4}}$ 